\title{
AN ANALYSIS OF THE IMPACTS OF THE FIRST PALESTINIAN UPRISING (INTIFADA) ON THE ISRAELI ECONOMY
}

\author{
Hamdullah BAYCAR* \\ Emrah ATAR**
}

\begin{abstract}
The Palestinian uprisings, Intifada, is one of the crucial milestones in the Palestinian-Israeli dispute. The first Intifada began in 1987 and ended (at least at the official level) in 1993 with Oslo Accords. The six years of protests affected both Israeli and Palestinian parts. In addition to the international area's criticism for Israel's brutal response, Israel's economy was also affected severely. Even though many Palestinians still criticize the Palestinian Authority for undermining the result of this series of protests, some argue that Oslo Accords are a significant gain for the Palestinians. Without concluding whether the negotiations went well, or Oslo Accords were a gain or a loss, this study argues that the economic aspect of protests was a factor behind the decision which led the Israeli part to negotiate and agree with Palestine. This study examines direct and indirect factors, such as the cost of general strikes, a boycott of goods, refusing to pay tax, and the rise in military expenditure.
\end{abstract}

Keywords: First Intifada, Oslo Accords, Israeli-Palestinian Conflict, Israel Economy.

\section{BİRINCI İNTIFADANIN İSRAIIL EKONOMISINNE ETKILLERININ ANALIZIi}

öz

Filistin'de yaşanan intifadalar, İsrail ile anlaşmazlığın en önemli yönlerinden birini temsil etmektedir. 1987'de başlayarak 1993'teki birinci Oslo Anlaşması ile sona eren ilk İntifada boyunca devam eden protestolar İsrail'i olduğu kadar Filistin bölgelerini de etkilemiştir. Bu süreçte İsrail'in orantısız şiddete dayanan yaklaşımı uluslararası kamuoyundan gelen eleştirilerin odağına otururken, ülke ekonomisini de büyük ölçüde etkilemiştir. Her ne kadar pek çok Filistinli, İsrail ile üst düzeyde ilk görüşmelere başlayan dönemin Filistin temsilcilerini halen protestoları sonucunu baltalamakla eleştirse de Oslo Anlaşmalarının Filistinliler açısından önemli kazanımlar getirdiğini savunanların sayısı da azımsanmayacak düzeydedir. Bu çalışma, müzakerelerin nasıl yürütüldüğü veya anlaşmaların başarılı olup olmadığı konusunda sonuca varmadan, Birinci İntifada'nın ekonomik yönünün İsrail'in Filistin ile müzakere ve anlaşmaya varmasını tetikleyen temel motivasyonlardan biri olduğunu savunmaktadır. Çalışma, bu süreçte yapılan grevlerin maliyeti, malların boykot edilmesi, vergi ödemenin reddedilmesi ve askeri harcamalardaki artış gibi doğrudan ve dolaylı maliyetleri inceleyerek Birinci İntifadanın İsrail'e olan ağır ekonomik yansımalarını açıklamayı hedeflemektedir.

Anahtar Kelimler: Birinci İntifada, Oslo Anlaşmaları, İsrail-Filistin Çatışmass, İsrail Ekonomisi.

Atıf: BAYCAR, H., ATAR, E. (2021). “Birinci İntifadanın İsrail Ekonomisine Etkilerinin Analizi”, İMGELEM, 5 (9): 565-578.

Citation: BAYCAR, H., ATAR, E. (2021). “An Analysis of the Impacts of the First Palestinian Uprising (Intifada) On the Israeli Economy”, IMGELEM, 5 (9): 565-578.

Başvuru / Received: 29 Ağustos / August 2021.

Kabul / Accepted: 27 Kasim / November 2021.

Derleme Makale / Review Article.

\section{INTRODUCTION}

The first Intifada (Palestinian uprising) began on December 9, 1987, after a controversial traffic accident in Gaza in which an Israeli truck killed four Palestinians and

\footnotetext{
* $\mathrm{PhD}$ candidate at the Institute of Arab and Islamic Studies at the University of Exeter, UK, E-mail: hb515@exeter.ac.uk, Orcid Number: 0000-0002-8720-9995

** Lecturer at Department of Political Science and Public Administration at Recep Tayyip Erdoğan University, Turkey, (Sorumlu Yazar / Correspondent Author), E-mail: emrah.atar@erdogan.edu.tr, Orcid Number: 00000003-1221-5415
} 
injured some others (Siniora 1988: 4-5). ${ }^{1}$ Even though the incident was not the only catalyst for this uprising, for the Palestinians, it motivated many Palestinians to revolt — particularly after the Israeli forces attempted to extinguish the following protests with military force, including shooting and killing some of the protestors (Cleveland and Bunton 2009: 475). The uprising spread to the West Bank right after it was initiated in Gaza, which had been occupied by Israel after the 1967 War. Since the occupation, the Israeli government had practiced rigid policies against the local Palestinians, which worsened over time (Said 1989: 23). Throughout the previous twenty years of the Intifada, the Palestinians repeatedly revolted against those policies (Peretz 1988: 964). When the Intifada started, though, the Israeli authority did not expect that the uprising would last longer than the others and that it would eventually result in the involvement of many international actors - most significantly, the US, the Soviet Union, Western Europe, and the Arab World (Peretz 1988: 964-965).

The Intifada differed from predecessors in multifaceted dimensions, including, but not limited to, the duration of the uprising, the costs accrued by both sides, the results, and the number of international parties involved. Even though the impacts of the Intifada are still among the most controversial topics within academia, it is doubtless that the Intifada began a new phase in this long-standing conflict (Neff 1997: 81; Konstantin et al. 2015). It is challenging to decide which side of the conflict was more affected by this Intifada, seeing as it is hard to determine which side profited or suffered. Nonetheless, it can be said that the Intifada had a significant impact on several dimensions of Israeli society, from the economy to democracy and from military policy to diplomacy. This study examines the Intifada effects on the Israeli state and society regarding economic factors.

It should be noted that this study aims neither to show that the economic impacts of the Intifada were the most important factors that led Israel to commence negotiations nor to exaggerate the value of its economic impacts. Instead, it demonstrates that the economy was one of the dimensions that the Israeli administration needed to consider due to the significant economic losses that the Israeli state and its society accrued. It is crucial to warn the reader that the monetary value mentioned in this paper should be considered in the context of that period and not that of today. As Shlomo Swirski (2005: 110), a scholar interested in this particular

\footnotetext{
${ }^{1}$ If not stated otherwise, "Intifada" refers to the first Intifada and will be used interchangeably with "uprising" throughout the paper.
} 
conflict, summarizes: "The Palestinians are paying a much heavier one [price], but this does not make the Israeli price any less significant."

This article is divided into three main sections to defend the claim better that the economic dimension of the Intifada was one of the dimensions that the Israeli government was obliged to take into account. First, the Intifada itself will be studied in order to understand the following parts better because this will help one to understand the intensity of the uprising and the fact that it caused a significant amount of instability and insecurity in the region, not to mention the importance of this incident in the international area. Second, the direct losses and costs that would be accrued due to the Palestinians will be studied under different subtitles; namely, the effects of these boycotts and strikes; the effects of refusing to pay taxes to the Israeli authority; the damage caused by the mass demonstrations that they organized; and the increase in military expenses. Third, the effects of this Intifada on the Israeli economy will be studied in terms of growth rate, investment, and tourism.

\section{The Intifada: An Intense Mass Uprising}

This part represents the Intifada in a general sense. This part will attempt to give a clearer sense of the intensity of the uprising and, consequently, the instability status of both Israel and Palestine. It was inevitable that this mass uprising would affect social and political life and the economies of both the occupied territory and Israel. This part of the paper is equally significant for three reasons: (1) it relates the direct cost of the Intifada to the different sectors of the Israeli/occupied territories' economies (e.g., agriculture, tourism, and construction); (2) it demonstrates how the Intifada caused instability in the region; (3) and, finally, it will provide the reader with an understanding of the overall situation surrounding the Intifada.

The Intifada was a mass uprising initiated by Palestinian youths after a long-standing occupation, humiliation, and suppression of the occupied territories by the Israeli government (Said 1989: 23). Since the Gaza and the West Bank occupation, Israel continuously increased the number of settlements in those territories. Not only did they increase the number of settlements in that territory, but they also simply tried to isolate the Palestinians from their lands by employing upon them numerous practices, from obliging them to carry an identity card to having them ask permission in order to hold meetings amongst themselves (Cleveland and Bunton 2009: 110-120). These practices would cause the Palestinian population to hold much resentment and anger against the Israeli government. Eventually, that anger and resentment would boil over into spontaneous protests, which, in the end, become an even more systematic 
and organized uprising against Israel under the Unified National Leadership (UNL) (Smith 2001: 414).

This mass uprising was postponed until the late 1980s because of the relatively better living and economic conditions of the Palestinian Arabs who lived in the occupied territories than the Palestinians who lived under Jordanian authority. Their wages were considerably better than the Palestinians who lived in Jordan, and their neighborhood was isolated from the Jewish settlements, preventing them from interfering in each other's lives. The number of Jewish immigrants in those areas was also not very high. However, the beginning of the 1980s brought many changes, both in the occupied territories and in Arab countries. Israel shifted to practicing more radical policies towards the Palestinians; for example, the Israelis started establishing new settlements for Jewish immigrants in the occupied territories. Eventually, they aimed to dispatch the Arabs from their lands entirely (Smith 2001: 414-415).

By the 1980s, the young population did not behave like previous generations. They were both more educated and less obedient. They were also unable to compare the relative prosperity and living standards of the occupied territories they were currently living under with the situation before the War of 1967 (O’Neil 1991: 55). This uprising was a popular reaction, and its proponents had many tools to impede the Israeli state from interceding in their actions. All the social classes participated in this popular uprising. General strikes and boycotts were two necessary tools utilized by this uprising (O’Neil 1991: 60-61).

Along with these tools, mass protests were also an important instrument that was used during this uprising. Moreover, even though the protesters' "guns" were stones, the Israeli soldiers responded with incommensurate brutalities, like shooting and beating the protesters. In turn, this led to a significant amount of international support for the protesters and against the Israeli state (O’Neil 1991: 60-62).

The monetary value presented here should be considered as the values of the 1980s and 1990s. Bearing this in mind, Israel's Gross Domestic Product (GDP) in 1988 was $\$ 43.89$ billion (World Bank 2016). However, the growth rate in GDP decreased from 6.1\% in 1987 to 3.6\% in 1988 and $1.4 \%$ in 1989. The growth rate in per-capita GDP also dropped from $4.6 \%$ in 1987 to $1.9 \%$ and $0.3 \%$ in the following years, respectively. The unemployment rate rose from $6.1 \%$ in 1987 to $8.9 \%$ in 1989 (Swirski 2005: 114-118). 


\section{The Direct Costs of the Intifada: General Strikes, Boycotts, and Other Expenses}

The Intifada was a popular uprising in which many economic tools were used to convince Israel to challenge its oppressive policies against the occupied Palestinian population. The Israeli Finance Minister of the time, Shimon Peres, said that the Intifada cost the Israeli economy between $\$ 1.5$ and $\$ 2$ billion per year (Shalev 1991: 154). The Israeli economy was affected particularly in some sectors such as construction, agriculture, and exports. An increase in military expenses and the refusal to pay state tax were also some of the direct and indirect costs of the Intifada. These elements will be studied under four subtitles: (1) the effect of the general strikes will be studied - particularly their effects on the construction and agriculture sectors; (2) the Palestinians' boycotting of Israeli goods; (3) the Palestinians' refusing to pay the taxes; (4) the added burden of Israel's having to spend extra money in order to maintain their military's presence in the occupied territories (seeing as the uprising lasted longer than expected).

\section{The General Strikes}

Palestinian workers were dominantly located in certain sectors of the Israeli economy, such as construction, agriculture, footwear, textiles, and some other sectors in which Israeli workers refused to work (Peretz 1990: 148). Thus, the absence of these workers and the subsequent decline in their work hours decreased those sectors' productivity. The workers who were from the territories were encouraged by their local leaders not to work for Israeli companies. In addition, the curfew and security measures that the Israeli Defense Forces (IDF) took were another obstacle in preventing them from going to work (Razin and Sadka 1993: 80).

It is estimated that the Palestinian residents of the territories provided $45 \%$ of employment in the agricultural sector. In 1988, after the start of the Intifada, the total employment in the Israeli agricultural sector dropped by $9 \%$ compared to 1987 . The drop caused a catastrophe for those businesses during the harvesting season (Rosen 1991: 375). This figure, however, does not portray the entire picture. For one thing, the work hours declined dramatically because the shops were not opening at all or opening at certain hours. For another, the wages the workers received increased a considerable amount. Thus, the losses to actual work hours were more dramatic than 9\% in 1988 (Razin and Sadka 1993: 80-82). Even though this section regards the general Intifada strikes, it is necessary to mention another problem that occurred in the Israeli agricultural sector but is not related to the strikes. During the Intifada, the agricultural sector suffered from a general sense of insecurity and a drop in sales. Many 
times, the agricultural fields were set on fire and destroyed; and, even if the fields were not destroyed, it was hard to find employees to harvests; and, even if the fields were harvested, it was difficult to find a market in which to sell that product due, not only to international factors but also to the boycotts — both of which will be mentioned further below (Rosen 1991: 375). Eventually, Jewish students were hired to harvest the fields, but no considerable success was still achieved. Although unemployment went up, Israeli farmers could not find enough workers to harvest their fields. At the end of 1988, Israeli farmers demanded that the government invite 2000 foreign agricultural workers into the country - even though the immediate number needed was 12000 (Peretz 1990: 148). It is also important to mention that the first months that the Intifada corresponded with the harvest period. Thus, even the first couple of weeks had devastating results on the Israeli agricultural sector. For example, an Israeli agricultural company, Agrexco, lost \$500000 just in December 1987 and January 1988 for not delivering its British orders (Rigby 2015: 171-172).

Another sector that suffered from the lack of Palestinian workers was construction. Even though it is hard to estimate the absence rate in this sector because the statistics are given annually, the construction sector relies on daily workers. Before the Intifada, approximately 40000 Palestinians worked in Israel in the construction sector (Peretz 1990: 148-149). According to the Israeli Central Bureau of Statistics, the lowest completed building in Israeli history between 1955 and 2007 was in 1988 (Central Bureau of Statistics: 2016). Therefore, Intifada had a severe impact on the Israeli construction sector.

\section{Boycotts on Goods}

The prominent activists during the Intifada encouraged their followers not to buy Israeli products whenever possible. This policy was successful to some extent, especially during the first year of the uprising. Aryeh Shalev lists some of the costs that the boycotts incurred: the industrial goods sold in the occupied territories, for instance, fell from $\$ 850$ million in 1987 to $\$ 250$ million in 1988; agricultural products also fell by around 60\% in 1988 when compared to 1987; the same occurred for textiles at around $18 \%$, as well as with some other sectors. Average factory exports decreased by around 20-30\% in 1988 (Shalev 1991: 155).

These boycotts harmed the Israeli economy while sometimes benefitted the local Palestinian economy. Some local factories, which, under normal conditions, would have gone bankrupt, for example, prospered during this time and survived (Shalev 1991: 151). 


\section{Refusing to Pay Taxes and Some Other Costs of the Uprising}

Palestinians who lived in the occupied territories were required to pay taxes to the Israeli government, but this was also one of the tools used against the government by the uprising's leadership. The aim was to strain the Israeli state as much as possible. Although there are no official statistics regarding tax revenues, the civil administration was forced to decrease the number of their services due to these lower tax revenues (Bishara 1989: 12-13). Another indication that the Israeli state suffered due to the occupied population's refusing to pay their taxes is that the Israeli government introduced new rules that required people to prove that they had paid their taxes to receive certain state services. For example, anyone who wanted to travel to Jordan was required to show such proof.

The uprising caused some other costs. For example, a hike in insurance rates occurred because frequent conflicts between Israeli soldiers and protesters often damaged buildings and shops. Also, many public vehicles were damaged during the Intifada. Indeed, 1260 buses were reported to have been damaged, of which 41 were destroyed. This example demonstrates how economically disastrous the Intifada was for the Israeli state.

\section{The Costs of the Demonstrations: An Increase in Military Expenses}

Unsurprisingly, such an intense uprising would increase military expenditures. When the uprising began, the Israeli Defense Forces fortified their military stations in Gaza and the West Bank with more soldiers. Also, they created new units in order to protect Jewish settlements from possible attacks (Swirski 2008: 16-17). The Israeli reserve service was also increased from 45 days to 60 days in a year, thereby costing an additional \$100-200 million per year to maintain (Bishara 1989: 11).

The Intifada increased the military units in Palestine. The IDF empower the existing military units and created new units in all parts of Palestine and also in occupied territories. While the IDF aimed to control the Palestinian territory, they aimed to prevent any attacks on the Jewish settlements. The creation of new units along with the allocation of new resources increased the military expenses (Swirski 2010: 18-19). The signing of the Oslo Accords did not decrease the budget again. It is estimated that from 1989 to 1993, around 5 billion NIS (in 2009 prices) budget was added to the defense expenditure (Swirski 2010: 20-21). 
The Effect of the Intifada's Intensity: Mass Demonstrations and the Destabilization of the Israeli Economy

It is not surprising that such an intense uprising and unstable situation in Israel and its occupied territories would affect the Israeli economy considerably. Even if no statistics and comments were available, one can easily expect that internal instability and conflict would harm the country's economy in several ways. It is doubtless that the Intifada would have affected the Israeli economy even more than just the direct costs already mentioned.

The previous section explained the direct economic implications of the Intifada on the Israeli economy. This section will examine the indirect economic impacts of the Intifada due to its intensity. Also, the international response to the Intifada and their economic connections will be explained. These impacts were among the reasons that encouraged the Israeli government to negotiate with the Palestinians.

\section{Growth Rate, Inflation, and Consumption}

The Israeli economy's growth rate declined and suffered considerably from 1973 and continued to worsen during the first quarter of the 1980s, with the monthly inflation rate reaching $30 \%$ in July 1985. In an attempt to recover its economy, the Israeli government implemented rigorous economic programs. The US also sent $\$ 1.5$ billion as an emergency fund for that exact purpose. It was not until 1987 that the Israeli economy showed considerable positive indications, with its growth rate reaching its peak since 1973. In addition, personal consumption and imports increased, while unemployment and inflation decreased dramatically (Rosen 1991: 371-372). The Intifada, which arose at just around the end of this stable and considerably good year, shifted that positive atmosphere into instability once more. Indeed, the growth in Gross Domestic Product was 6.1\% in 1987 but decreased dramatically in the following two years to $3.6 \%$ and 1.4\% in 1988 and 1989, respectively (Swirski 2008: 297-312).

Even though the growth declined from $6.1 \%$ to $1.4 \%$ in three years, the decline in growth rate would be more devastating if it was not thanks to the mass migration from the former Soviet Union's land to Israel. It was thanks to this migration the economy functioned better than it would otherwise (Swirski 2010: 13).

David Fielding (2003: 297-312) links this unstable period of the Intifada with consumption and saving. Fielding successfully concludes that the low saving rates during this uprising were mainly due to the instability and conflict of the Intifada itself. Since saving and 


\section{Hamdullah BAYCAR - Emrah ATAR}

consumption rates are significant indicators of growth in an economy when foreign debt is many impossibilities, it is presumed that Israel should have had a more significant growth rate during this period had the uprising not occurred because its economy was then showing signs of recovery and ameliorating its deficiencies (Fielding 2003: 297).

\section{The Deterioration of the Israeli Image in the Western World}

The Intifada had a significant effect on Israel's image in Europe and the US. The aggrieved and victim image of Israel would shift to one of brutality and discrimination. Fouad Moughrabi analyzes eight surveys in the US regarding its public attitude towards Israel. He concluded that most of the surveys showed that Israel's policies were quite harsh and unacceptable (Moughrabi 1990: 241-243). This shift in Americans' attitudes toward Israel was important because Americans, subsequently, started criticizing the country's policy of providing financial aid to Israel - especially since US aid to Israel comprised a significant share of the Israeli budget. The White House, for instance, criticized the US Congress's approval of reducing the interest rate on Israeli debt - something which, in the end, profited Israel around $\$ 2$ billion (Neff 2016: 81). Even though the US did not stop sending the promised aid to Israel, the public — including many politicians - were not as comfortable sending them aid as they were in the past. This, in turn, would give rise to the administration's pressuring Israel to commence negotiations with the Palestinians of its occupied territories. Because US aid was an important factor for the Israeli economy, Israel took this insistence very seriously.

The Israeli image worsened in Europe as well. The economic sanctions which some European countries levelled on Israel in response to the 1982 Israeli invasion of Lebanon have leveled yet again in 1989 because of Israel's unjust treatment of the Palestinians in its occupied territories. Israel's attempt to close a new trade pact with the Europeans was also postponed due to these exact reasons (Anti-Defamation League 2016). In addition to this, several Northern European countries started boycotting Israeli goods (Paul 1988: 15).

\section{Tourism}

Tourism was one of the sectors of the Israeli economy which the Intifada affected. Tourism revenues were significant for the Israeli economy because Israel needed foreign currency in order to be able to maintain the stability of its economy in international finance (Rosen 1991: 377). Israeli tourism revenues declined in some significant instability that it faced, such as in 1981 and 1982 due to the Lebanon War, and in 1986 due to some casualties occurred between Palestinians and Israeli Defense Force (Rosen 1991: 377). During the Intifada period, 
the Israeli economy experienced the same downward spiral in the influx of foreign currencies. In 1988, tourism revenues dropped by $15 \%$ approximately when compared to the previous year (Shalev 1991: 155). Though James Paul suggests that a considerable amount of those tourists were Jews who lived outside of Israel and who went there to bolster the Israeli state by supporting Jewish organizations there (Paul 1988: 15).

International tourism to Israel reached its peak in the year when the Intifada began below 1.5 million tourists in 1987. From 1987 to 1991 (when the Gulf War began), the number of tourists decreased until it reached around 1 million people in 1991. It is in 1992 the number reach back to the year when Intifada began (Cohen 2014). From 1987 to 1988, the number of tourists declined 15\%, in the following year increased 10\%, while in 1990 suffered another 5\% (Mansfeld 1994: 651).

\section{Investment and Unemployment}

Fielding (2003: 159-161) argues that political stability is important for investment and he states that the Intifada created a significant degree of political instability in Israel and finally caused a decline in investments in the country and its businesses. The most significant indicators that prove that the region was insecure and unstable were the number of casualties incurred on either side. The strict Israeli security measures did not halt the destabilization in the country making the peace process inevitable (Fielding 2003: 176-177).

Unemployment affected both sides during the uprising as well. One of them reflects the unemployment of the Palestinians coming from the occupied territories to farm Israeli land, as mentioned above. The Intifada harmed the Israeli unemployment rate, with the unemployment rate increasing from 6.1 in 1987 to $8.9 \%$ in 1989 (Swirski 2005: 110-120).

\section{CONCLUSION}

The first Palestinian Intifada of 1987 is remembered as one of the most critical milestones in the long-lasting Arab-Israeli conflict. The first Intifada was not the first uprising initiated by the Palestinians, but it succeeded to be one of the most influential ones in this conflict's history. It finally ended with Israel's recognition of the Palestinians. The uprising itself started spontaneously and very humbly, but in a short while, it created its own leadership, which would, in turn, affect the Palestinians' destiny up till this day. This paper studied the economic impacts of the first Palestinian uprising on the Israeli economy. The impacts of the Intifada are both complex and multifaceted, with the Intifada having affected both societies significantly 
concerned, from their economies to human rights. The paper argues that the economic impacts of the Intifada were of such importance to the Israeli state that the state could do nothing but take them into account. This paper did not argue that the economic impacts were the most important outputs of the Intifada, but considering the economic situation of Israel at that time, those costs were not something that could, or should, have been neglected. The paper was divided into three main sections. The first section explained the Intifada more generally, providing only its essential outlines. The second section related to the direct economic impacts the Palestinians caused. Finally, the last section analyzed the impacts of the uprising in terms of their level of intensity, insecurity, instability, and international response.

As mentioned in the first part, the Intifada began due to the Palestinians' long dissatisfaction with Israeli authority. It was not started only because of differences in identity but also due to the insulting policies that the Israeli state implemented against the local population. During the Intifada, the Palestinians and their leadership tried to enlist many tools to oblige Israel to liberate them or restore and modify their situation. General strikes, boycotts, refusing to pay their taxes, and mass demonstrations were all tools that they employed.

The Israeli sectors most affected by the strikes were the construction, agriculture, textile, and footwear sectors (i.e., those sectors that require unskilled workers). The Israeli government always attempted to overcome those measures by implementing their own. For instance, the Israeli government first tried to solve this problem by employing Israeli students and encouraging unemployed Israelis to work in those sectors, but these two policies were not enough for that sector's demand. They finally had to import foreign workers from various countries. Though some statistics were given about the number of people who left their jobs, it is hard to know the exact number. It is known that, during the first year of the uprising, in particular, the construction and agriculture sectors suffered significantly. Indeed, it is estimated that, in the construction sector alone, $\$ 16$ million was lost monthly, accruing to an $8 \%$ loss to the total economic activity in this sector, simply because of the Palestinian workers' absence (Bishara 1989: 12-13).

The Palestinians also boycotted Israeli goods. Indeed, they were even boycotted by Arab and European countries. This benefited the local Palestinian merchants since they could not compete with Israeli goods under normal circumstances. Israeli industrial goods alone dropped from $\$ 850$ million in 1987 to $\$ 250$ million in 1988 (Shalev 1991: 155). Therefore, if all of 
Israel's products are added to this boycott, one can imagine how much Israel suffered from those boycotts.

The tax revenues collected from the territories were also one of Intifada's tools. Although no official reports show these losses, it is expected to be quite considerable, seeing as the Israeli authority decreased the number of public services, they offered due to that decrease in tax revenues. One of the other effects that the Intifada had on the economy was the conflicts ensued. For instance, the insurance rate skyrocketed because many buildings and buses were damaged due to the conflict between Israeli security forces and protesters.

Due to the abovementioned costs of Intifada, the country's growth rate also slowed. Even though it was $6.1 \%$ in 1987 , it dropped to $3.6 \%$ and $1.4 \%$ in the first two years of the Intifada, respectively. This slowdown in the growth rate subsequently increased the unemployment rate in Israel and would damage the saving/consumption balance.

Tourism was also one of the sectors most affected by the Intifada. This mass uprising caused Israel and its territories to be thought of as being insecure and unstable. Foreign tourists, therefore, preferred not to venture traveling there. Many of these foreign tourists were Jews who lived outside Israel to support Israel in their war. The last factor mentioned in this paper regards how foreigners perceived Israel. The Israeli image suffered due to the harsh response of the Israeli Defense Force towards Palestinian protesters. It was widespread to see the Israeli Forces shooting or beating the Palestinian children who were responding to the Defense Force with their stones. The legitimacy of the Israeli occupation, therefore, came to be questioned. This, in turn, led some European countries to boycott Israeli goods. Even though many in the US changed their opinion about Israel as well, it did not affect the US's providing Israel aid in practice; rather, it raised big opposition against those aids.

To sum up, the Intifada had a significant effect on both Israel and its territories' economies. This paper argued that the Israeli economy suffered to such an extent that the Israeli government had no other option than to consider negotiations with the Palestinians. Moreover, even though it might not be the most important reason, it still, nevertheless, is an important reason.

\section{REFERENCES}

Anti-Defamation League. (2016). Europe and Israel: Where Politics and Economics Do Not Meet. http://archive.adl.org/international/eu-print.html 
Assaf, R., Efraim, S. (1993). The Economy of Modern Israel: Malaise and Promise, Chicago: The University of Chicago Press.

Bishara, A. (1989). Israel Faces the Uprising: A Preliminary Assessment, Middle East Report, $157,6-14$.

Central Bureau of Statistics. (2016). Israel in Statistics 1948-2007. http://www.cbs.gov.il/statistical/statistical60_eng.pdf/

Cleveland, W. L., Bunton, M. (2009). A history of the Modern Middle East, Boulder: Westview Press.

Cohen, E., (2014). Tourism and Terror: A case study: Israel 1948-2012, International Journal of Religious Tourism and Pilgrimage, 2(1), 13-26.

Don, P. (1988). Intifadeh: The Palestinian Uprising, Foreign Affairs, 66, 964.

Don, P. (1990). Intifada: The Palestinian Uprising, Boulder: Westview Press.

Edward, S. (1989). Intifada and Independence, Social Text, 22, 23-39.

Fielding, D. (2003). Counting the cost of the Intifada: Consumption, saving and political instability in Israel. Public Choice, 116(3), 297-312.

Fielding, D. (2003). Modelling political instability and economic performance: Israeli investment during the Intifada, Economica, 70(277), 159-186.

Fouad, M. (1990). The Intifada in American Public Opinion, J. Nassar and R. Heacock (Ed.), in Intifada: Palestine at the Crossroads (241-256), New York: Praeger Publishers.

Hanna, S. (1988). An Analysis of the Current Revolt, Journal of Palestine Studies, 17(3), 3-13.

James, P. (1988). Israel and the Intifadah: Points of Stress, Middle East Report, 154, 13-16.

Mansfeld, Y. (1994). The Middle East Conflict and Tourism to Israel, 1967-90, Middle Eastern Studies, 30(3), 646-667.

Neff, D. (2009). Middle East History: It Happened in December; The Intifada Erupts, Forcing Israel to Recognize Palestinians, The Washington Report on Middle East Affairs XVI, (4), 81.

O'Neil, B. (1991). The Intifada in the Context of Armed Struggle, Freedman (Ed.), in The Intifada: Its Impact on Israel, the Arab World, and the Superpowers (37-69), Miami: Florida International Press.

Rigby, A. (2015). The First Palestinian Intifada Revisited, Sparsnas: Irene Publishing.

Rosen, H. (1991). Economic Consequences of the Intifada in Israel and the Administrated Territories, Freedman (Ed.), in The Intifada: Its Impact on Israel, the Arab World, and the Superpowers (370-400), Miami: Florida International Press.

Shalev, A. (1991). The Intifada Causes and Effects, Jerusalem: Westview Press.

Shlomo, S. (2005). The Price of Occupation: The Cost of the Occupation to Israeli Society, Palestine - Israel Journal of Politics, Economics, and Culture, 12, 110-120.

Shlomo, S. (2008). The Cost of Occupation: The Burden of the Israeli-Palestinian Conflict, 2008 Report. Tel Aviv: Adva Center.

Shlomo, S. (2010). The Cost of Occupation: The Burden of the Israeli-Palestinian Conflict 2010 Report, Tel Aviv: Adva Center. 
Smith, C. D. (2004). Palestine and the Arab-Israeli conflict, Bedford/St. Martin's

World Bank. (2016). GDP at Market Prices. http://data.worldbank.org/indicator/NY.GDP.MKTP.CD/countries/IL?page=6\&display= default

Yanovskiy, K., Zatcovetsky, I. \& Rotenberg, V. S. (2015). The First Intifada, the Oslo Accords, and the Escalation of Terror: Causalities Revisited. 